\title{
Can Homeopathy, a Particularly Mild Therapeutic Approach, Survive and Grow in a World of Violence?
}

\author{
George Vithoulkas ${ }^{10}$ \\ ${ }^{1}$ University of the Aegean, Greece \\ Homeopathy 2020;109:179-181.
}

Address for correspondence George Vithoulkas, Alonissos, North Sporades, 37005 Greece (e-mail: george@vithoulkas.com).

\author{
Abstract \\ Keywords \\ - homeopathy \\ - society \\ - violence \\ - aggression \\ - personalized \\ treatment
}

This short treatise addresses a philosophical question concerning the place of homeopathy in our modern world. The question raised is whether a therapeutic system as peaceful, mild, and non-violent as homeopathy can survive and grow within a society that often displays the opposite characteristics.

Much of contemporary society is more interested in fast and impressive cures, even if these may also bring side effects; whereas homeopathy can offer solutions with a personalized approach that requires long hours of case study by the homeopath to find the correct personal remedy that aims to bring about positive results, which the therapy can produce in deep chronic diseases.

The conclusion drawn is that homeopathy does not readily fit within a modern and violent society that prefers quick and invasive solutions to its clinical problems.
The title of this article is a legitimate question that has been torturing my mind for almost three decades and has been preoccupying me more and more recently. Its answer is crucial for me and for my students, who have been applying this therapeutic approach. Even though homeopathy's therapeutic potential has been apparent to millions of patients and to many thousands of homeopathic physicians, and despite numerous incurable chronic cases published in medical journals, ${ }^{1-15}$ we still have a long way to go before seeing homeopathy become a recognized medical specialty. It is unclear whether homeopathy will ever be able to take its rightful place within the field of general medicine.

It is a strange paradox that, despite evidence that classical homeopathy can successfully treat chronic conditions that are considered incurable with conventional medicine, homeopathy still remains an untouchable issue for the majority of medical authorities. If, in conventional medicine, a cure were found for a previously incurable chronic condition, such discovery would make world news headlines; but reports of corresponding homeopathic cures are met by total silence! I have tried to think what has happened with homeopathy and why its amazing effects are not appreciated as much as is deserved.
Homeopathy is a therapeutic system aiming at re-establishing the body's mental, emotional, and physical balance. It is a most "peaceful" therapeutic system, which has existed for two centuries with an impressive record of cures, and yet it has remained in the background all that time. In trying to give an explanation for the paradox, I shall start with an example from daily clinical practice.

A stressed, depressed, insecure, irritated, and troubled patient, who is under the strain of daily hardships and who suffers also from a multitude of physical discomforts and aches, seeks help from homeopathy. The homeopath will investigate the conditions that brought about such an imbalance and, sometimes after hours of meticulously investigating and studying the case, will try to find the correct substance-a personal remedy-for this person to "re-set" 16 and enable a return to a healthy state. Once this personal remedy has been taken, the patient's health is restored, with an overall balance and a sense of well-being.

The concern is how long this physical, emotional, and mental balance ${ }^{17}$ can last in a sensitive patient when he or she is living in a world that is so overtly influenced by violence and aggression? How long can the immune
License terms Homeopathy
DOI https://doi.org/

10.1055/s-0040-1710020. ISSN $1475-4916$.
February 17, 2020

accepted after revision

March 2, 2020

published online

May 14, 2020

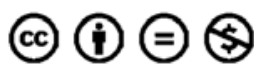


system-the inner defense of the organism-remain in balance in the midst of a polluted atmosphere, with foods filled with chemicals, and on top of these living within a maelstrom of the ruthless competition and aggression so prevalent in society? Experience has shown that the restored balance will not stay for very long: under such stresses the sensitive patient will once again start feeling unwell. The problem is that once an organism is back to a balanced state, it is much more vulnerable to stress than an already compromised organism.

In many instances, the patient will not return to homeopathy, thinking that the cure should have lasted for ever. The fact is that patients living in modern society have to face many obstacles to their health. The modern society that we have created incites people to ever greater aggression. The accumulation of material possessions above everything else, at times taking the form of inhuman behavior, is normal practice. Meritocracy has long disappeared from the collective consciousness, while the seizure of power by any means is the accepted norm. All these conditions create barriers for the health of people through anxiety, phobias, and depression.

Those who seek and promote spiritual advancement for themselves and for society, refusing to compromise their own conscience and moral ethics, are today considered a meagre and weak minority. Only a few such individuals will be found among different groups of civilians-for example, among scientists, artists, homeopathic physicians, social workers, religious or spiritual seekers-but all such people are either marginalized due to their peaceful temperament or those who are still fighting will be exhausted since the majority of society is so imbued in violence and corruption that almost automatically negates any efforts for change by small groups who are seeking peace and justice. Yet, it is such groups that deserve and appreciate the care provided by this peaceful therapy. Those people, despite being pillars of society, feel powerless to impose a system of therapy that has served them so well and so efficiently.

Violence, in all its forms-between states, between nations, between terrorist groups, by anyone who possesses any power over more vulnerable groups-is prevailing in today's world. It is thus interesting that conventional medicine, with its generally invasive approach, fits so well with the mentality of today's society and therefore dominates the contemporary health sector. To develop the original question of this article: in such a society, is it possible that homeopathy-a non-violent therapeutic system that tries to restore inner peace and balance-can survive and grow?

Unless a person, especially the most perceptive, is able to put up a remarkable resistance to the general trends of corruption and aggression, he or she will find it extremely difficult to maintain their mental emotional balance. Living in environments where corruption and self-interest prevail can drive sensitive people, in order to survive, to compromise their conscience and their own moral ethics. As a result, such behavior makes them deeply ill at the outset of their efforts. Under those conditions it is difficult for a fragile person to maintain his or her health and remain well for long, even under the best homeopathic care.
It is quite logical to conclude that homeopathy is not a therapeutic approach suited for a modern "developed" society, that it will never be widely practiced in our contemporary world, and that it will never become truly adopted by medical schools-apart from a few avant-garde medical institutions that have visionary leadership. That is why I have always maintained that conventional medicine in the developed world should not be afraid that homeopathy will ever invade its space.

Homeopathy has earned, and will keep earning, the approval of only those few practitioners with high ideals who still believe in a free and just society-an ideal society-which may emerge after much time and much suffering. A mild form of medical practice will not be given room to thrive in tomorrow's world, unless and until the days of constant assault on moral values are confined to the past. But, realistically, will that happen?

My sense is that, even if a prophet with extraordinary qualities and power were to emerge tomorrow, inciting the masses to help eliminate violence and corruption and bring about peace and justice on earth, what would be the most likely scenario? Our modern society would kill the prophet!

\section{Conflict of Interest}

None declared.

\section{References}

1 Alibeu JP, Jobert J. Aconite in homeopathic relief of post-operative pain and agitation in children [article in French]. Pediatrie 1990; 45:465-466

2 Chabanov D, Tsintzas D, Vithoulkas G. Levels of health theory with the example of a case of juvenile rheumatoid arthritis. J Evid Based Integr Med 2018;23:2515690X18777995

3 Chapman EH, Weintraub RJ, Milburn MA, Pirozzi TO, Woo E. Homeopathic treatment of mild traumatic brain injury: a randomized, double-blind, placebo-controlled clinical trial. J Head Trauma Rehabil 1999;14:521-542

4 Denisova TG, Gerasimova LI, Pakhmutova NL, Mahesh S, Vithoulkas G. Individualized homeopathic therapy in a case of obesity, dysfunctional uterine bleeding, and autonomic dystonia. Am J Case Rep 2018;19:1474-1479

5 Fisher P, Greenwood A, Huskisson EC, Turner P, Belon P. Effect of homeopathic treatment on fibrositis (primary fibromyalgia). BMJ 1989;299:365-366

6 Itamura R, Hosoya R. Homeopathic treatment of Japanese patients with intractable atopic dermatitis. Homeopathy 2003;92:108-114

7 Lamont J. Homeopathic treatment of attention deficit hyperactivity disorder: a controlled study. Br Homeopath J 1997;86:186-200

8 Mahesh S, Jaggi L, Jaggi A, Tsintzas D, Vithoulkas G. Individualised homeopathic therapy in ANCA negative rapidly progressive necrotising crescentic glomerulonephritis with severe renal insufficiency - a case report. J Med Life 2019;12:49-55

9 Mahesh S, Mallappa M, Tsintzas D, Vithoulkas G. Homeopathic treatment of vitiligo: a report of fourteen cases. Am J Case Rep 2017;18:1276-1283

10 Mahesh S, Mallappa M, Vithoulkas G. Embryonal carcinoma with immature teratoma: a homeopathic case report. Complement Med Res 2018;25:117-121

11 Mahesh S, Shah V, Mallappa M, Vithoulkas G. Psoriasis cases of same diagnosis but different phenotypes-management through individualized homeopathic therapy. Clin Case Rep 2019;7:1499-1507

12 Tenzera L, Djindjic B, Mihajlovic-Elez O, Pulparampil B, Mahesh S, Vithoulkas G. Improvements in long standing cardiac pathologies by individualized homeopathic remedies: a case series. SAGE Open Med Case Rep 2018;6:2050313X18792813 
13 Tsintzas D, Jaggi A, Jaggi L, Mahesh S, Vithoulkas G. Heterotopic ossification in a 7-year-old female patient treated with individualized homeopathy: a case report. Clin Case Rep 2019;7: 2526-2533

14 Văcăraş V, Vithoulkas G, Buzoianu AD, et al. Homeopathic treatment for postpartum depression: a case report. J Evid Based Complementary Altern Med 2017;22:381-384
15 Vithoulkas G, Văcăraș V, Kavouras J, et al. Homeopathic treatment for prolonged postoperative coma: a case report. J Med Life 2017; 10:118-121

16 Vithoulkas G. Levels of Health. Alonissos, Greece: International Academy of Classical Homeopathy; 2019

17 Vithoulkas G. The Science of Homeopathy. New York: Grove Press; 1981 